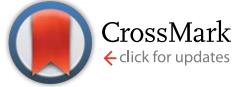

Cite this: RSC Adv., 2016, 6, 55848

Received 23rd March 2016

Accepted 1st June 2016

DOI: 10.1039/c6ra07659a

www.rsc.org/advances

\section{Nanoformulations of anticancer thiosemicarbazones to reduce methemoglobin formation and improve anticancer activity $\dagger$}

\author{
Britta Fischer, $\dot{t}^{\mathrm{a}}$ Kushtrim Kryeziu, $\dot{t}^{\mathrm{b}}$ Sebastian Kallus, ${ }^{\mathrm{a}}$ Petra Heffeter, ${ }^{\text {bc }}$ \\ Walter Berger, ${ }^{\text {bc }}$ Christian R. Kowol ${ }^{* a c}$ and Bernhard K. Keppler ${ }^{\text {ac }}$
}

\begin{abstract}
Triapine is a promising anticancer thiosemicarbazone which was investigated in multiple clinical trials, where it was active against leukemia but not against solid cancers. This is probably based on insufficient drug levels in the tumor due to a short plasma half-life. Therefore, we encapsulated Triapine into polymeric nanoparticles and remote-loaded liposomes to improve the drug pharmacokinetics as well as targeted delivery. However, burst release of Triapine from both nanoformulations was observed, making the synthesis of two novel Triapine derivatives necessary in order to improve the remote-loading properties. Indeed, the encapsulation efficiency increased and for one derivative also the desired continuous drug release was in line with a strongly reduced cytotoxic activity against cancer cells. In vivo studies of this most promising formulation demonstrated a significant increase in survival of the animals compared to the free drug. Finally, we investigated drug-induced methemoglobin formation, a frequently observed side effect of thiosemicarbazones, which was completely prevented by the liposomal formulation.
\end{abstract}

\section{Introduction}

$\alpha$-N-heterocyclic thiosemicarbazones are promising candidates for cancer therapy. Regarding the mode of action, it is assumed that they interact with (intracellular) iron via their tridentate NNS donor atoms. One enzyme, which is known to be very sensitive to disturbance of the iron levels, is ribonucleotide reductase (RR), responsible for the synthesis of DNA building blocks. ${ }^{1}$ Since fast proliferating tumor cells are frequently characterized by RR overexpression, this enzyme represents a promising and convenient target for cancer chemotherapy. ${ }^{2}$ It is believed that intracellularly formed thiosemicarbazone-iron complexes destroy the tyrosyl radical of the R2 subunit of RR (probably by direct interaction). ${ }^{3}$ However, treatment of cancer cells with thiosemicarbazones also resulted in several other effects like cell cycle arrest via c-myc and p21 as well as activation of diverse stress kinase pathways. ${ }^{4}$ Finally, some

${ }^{a}$ Institute of Inorganic Chemistry, University of Vienna, Waehringer Str. 42, 1090 Vienna, Austria. E-mail: christian.kowol@univie.ac.at; Fax: +43-1-4277-52680; Tel: +43-1-4277-52609

${ }^{b}$ Institute of Cancer Research and Comprehensive Cancer Center, Medical University Vienna, Borschkegasse 8a, 1090 Vienna, Austria. E-mail: petra.heffeter@ meduniwien.ac.at; Fax: +43-1-40160-957555; Tel: +43-1-40160-57557

${ }^{c}$ Research Platform "Translational Cancer Therapy Research", University of Vienna, Medical University of Vienna, Vienna, Austria

$\dagger$ Electronic supplementary information (ESI) available. See DOI: 10.1039/c6ra07659a

\$ These authors contributed equally to this work. thiosemicarbazones have also been suggested to interact with the cellular copper homeostasis., ${ }^{\mathbf{5 , 6}}$

With regard to clinical investigations, 3-aminopyridine-2carboxaldehyde thiosemicarbazone (Triapine; Scheme 1) is the most prominent representative of $\alpha$-N-heterocyclic thiosemicarbazones, as it has been already investigated in more than 30 clinical phase I/II trials. In addition, currently a novel thiosemicarbazone, di-2-pyridylketone-4-cyclohexyl-4-methyl-3thiosemicarbazone (DpC) is entering clinical phase I studies. ${ }^{7}$ However, so far no iron chelation-based therapy has been approved for cancer therapy. In case of Triapine, it is also worth noting that the clinical evaluation revealed mainly activity against hematological cancer types (e.g. advanced leukemia ${ }^{\mathbf{8} 9}$ ), but showed disappointing results as monotherapy against solid tumor types like non-small-cell lung cancer $^{\mathbf{1 0}}$ and renal cell<smiles>NC(=S)N/N=C/c1ncccc1N</smiles>

Scheme 1 Triapine and its Fe ${ }^{\text {III }}$ complex. 
carcinoma. ${ }^{11}$ The exact reasons are still unknown. We were recently able to show that Triapine is characterized by a very short plasma half-life time, which together with its transient activity results in rapid tumor re-growth in mice upon therapy cessation. ${ }^{\mathbf{1 2}}$ Thus, the current hypothesis is that plasma levels of Triapine are probably insufficient for drug delivery and longlasting maintenance of RR inhibition in solid tumor nodules. In addition, clinical trials indicated that interaction of Triapine with the iron-rich red blood cell compartment leads to the development of methemoglobinemia in the majority of the treated patients. ${ }^{13}$ Consequently, there is an urgent need for new strategies to increase the plasma half-life and tumorspecificity of thiosemicarbazones.

Nanoparticulate drug formulations would be an ideal strategy, as encapsulation of the drug would offer distinctly prolonged plasma half-life, and additionally specific tumor accumulation via the enhanced permeability and retention (EPR) effect. ${ }^{14}$ This effect allows nanoformulations to enrich in the tumor tissue due to leaky blood vessels and the absence of an effective lymphatic drainage system. ${ }^{15}$

In this study, we investigated, on the one hand, encapsulation of Triapine into the polymer matrices poly(lactic acid) (PLA) and poly(lactide-co-glycolide) (PLGA), since, both are biodegradable, biocompatible and are approved by the US Food and
Drug Administration (FDA) as therapeutic drug carriers in humans. ${ }^{\mathbf{1 6}}$ On the other hand, we tested encapsulation into liposomal formulations by the remote loading approach, which is one of the best-studied preparation methods for liposomes with e.g. Doxil® (liposomal doxorubicin) as clinically approved representative. ${ }^{\mathbf{1 7}}$ In addition, two novel Triapine derivatives were synthesized possessing a weak base amine, as such modifications were already reported to improve the loading and stability of liposomal formulations in case of gemcitabine ${ }^{18}$ or docetaxel. ${ }^{19}$ The novel nanoformulations were physicochemically characterized and the drug-release behavior was correlated with the cytotoxicity in comparison to the free drugs. For the most promising formulation, cell uptake studies were performed and the anticancer activity was evaluated in vivo. Finally, the ability of the nanoformulation to prevent methemoglobin formation was studied.

\section{Results and discussion}

\section{Polymeric nanoparticles - preparation and characterization}

Two different Triapine-loaded nanoparticles were synthesized using the nanoprecipitation method. As polymer matrices, the biocompatible and biodegradable polylactic acid (PLA) and poly(lactide-co-glycolide) (PLGA) were used. The encapsulation

A

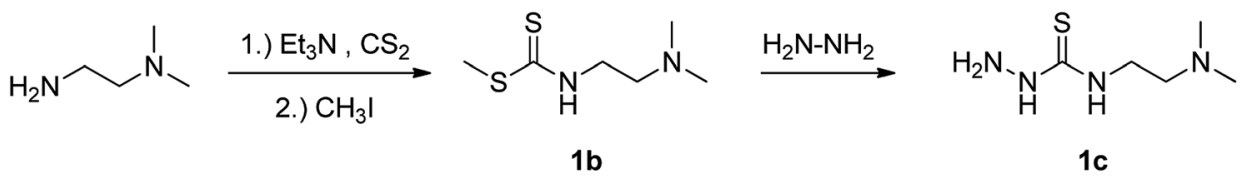<smiles>CC(C)(C)OC(=O)Nc1cccnc1C=O</smiles>

2.) $\mathrm{HCl}$<smiles>CN(C)CCNC(=S)N/N=C/c1ncccc1N</smiles>

B

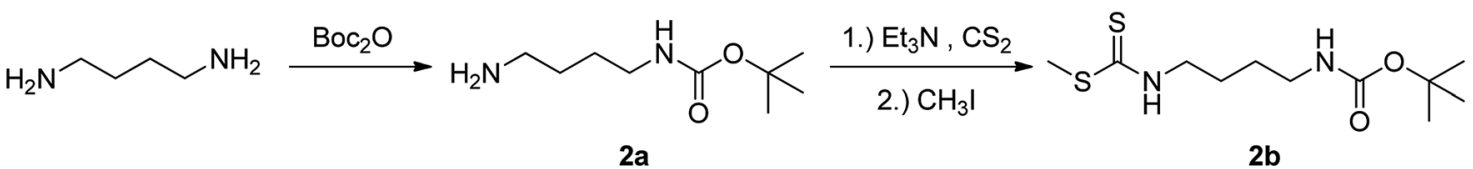<smiles>CC(C)(C)OC(=O)NCCCCNC(=S)NNCCN</smiles> 
Table 1 Characterization of the liposomes

\begin{tabular}{llll}
\hline $\begin{array}{l}\text { Encapsulated } \\
\text { drug }\end{array}$ & $\begin{array}{l}\text { Average size }(\mathrm{nm}) \\
\text { of the liposome }\end{array}$ & PDI & $\begin{array}{l}\text { Encapsulation } \\
\text { efficiency }(\%)\end{array}$ \\
\hline Triapine & $47 \pm 1$ & $<0.15$ & $19 \pm 9$ \\
$\mathbf{1}$ & $55 \pm 1$ & $<0.15$ & $52 \pm 5$ \\
2 & $50 \pm 1$ & $<0.15$ & $52 \pm 4$
\end{tabular}

of Triapine was performed by addition of acetone solutions of the respective polymer and the drug to an aqueous solution of the surfactant (Tween 80). The nanoparticles were produced in triplicate and characterized concerning their size, polydispersity index (PDI), zeta potential and encapsulation efficiency (Table S1†). The dynamic light scattering (DLS) data showed particle sizes between 110 and $130 \mathrm{~nm}$ (ESI Fig. S1 and S2 $\dagger$ ) with a PDI $<0.15$ indicating very homogeneous nanoformulations. The electrostatic repulsion of the particle surfaces (zeta potential) was negative at $-14 \pm 1 \mathrm{mV}$ for the PLA and $-8 \pm 1 \mathrm{mV}$ for the PLGA nanoparticles, which is in accordance with the presence of terminal carboxylic acid groups in the polymers. ${ }^{20}$ The encapsulation efficiency (EE) of Triapine was determined right after production by evaporation of the solvent and dissolving the thin film in a mixture of acetone and dichloromethane $(1: 1)$. The resulting solution was analyzed for Triapine content by UV-Vis spectroscopy revealing a quite low EE for both polymers $(<25 \%)$.

\section{Drug release and anticancer activity of Triapine-loaded nanoparticles}

Drug release from the Triapine nanoparticles was investigated using the dialysis bag diffusion technique. ${ }^{21}$ To this end, the concentration of released Triapine in the outer compartment was measured by fluorescence spectroscopy at various time points with an excitation wavelength of $368 \mathrm{~nm}$ and an emission wavelength of $455 \mathrm{~nm}$. Noteworthy, the gained release data from these particles is strongly influenced, on the one hand, by the partition coefficient of the drug between the polymer and the aqueous phase and, on the other hand, by diffusion flux of the drug across the membrane. ${ }^{22}$ Consequently, dialysis of free Triapine was performed as a reference and accounted for $100 \%$ drug release. After two hours under physiological conditions at $37{ }^{\circ} \mathrm{C}, \sim 80 \%$ of Triapine was released from PLGA and $96 \%$ from PLA nanoparticles (Fig. S3†). This indicates that there are either only weak interactions between the drug and the polymer ${ }^{23}$ and/ or a high surface location of the drug. ${ }^{24}$

In line with these data, MTT assays performed on SW480 colon and A2780 ovarian cancer cells after $72 \mathrm{~h}$ drug incubation revealed no difference in the activity of Triapine-loaded nanoparticles to free Triapine (Table S2 and Fig. S4†). As expected, the unloaded nanoparticles did not show any activity in these tests. Notably, amphiphilic co-polymer nanoparticles with 2benzoylpyridine 4-ethyl-3-thiosemicarbazone also showed similar cytotoxicity compared to the free drug after $48 \mathrm{~h}$ incubation, ${ }^{25}$ although after $48 \mathrm{~h}$ only $\sim 50 \%$ of the drug was released in PBS pH 7.4.

Overall, these data indicate that, although, drug encapsulation of Triapine within polymeric nanoparticles has been successfully achieved, the resulting nanoparticles showed insufficient stability for biological use. Hence, encapsulation into liposomes as an alternative strategy of nanoformulation was investigated.

\section{Liposomal formulations}

One of the best studied preparation methods for liposomes is the so-called remote loading approach, which is also for example used in the preparation of Doxil® (encapsulated doxorubicin) as the most prominent clinically approved representative. ${ }^{17}$ In general, doxorubicin can be considered an ideal drug for this loading approach, since it contains a crucial weak base amine that is protonated inside the ammonium sulfatecontaining $(\sim \mathrm{pH} 5)$ liposomes. Moreover, in order to ensure optimal remote loading by the ammonium gradient, the loaded molecules should have a $\log D$ at $\mathrm{pH} 7$ in the range of -2.5 to 2 and a $\mathrm{p} K_{\mathrm{a}} \leq 11 .{ }^{26}$ Also Triapine fits to these prerequisites with a $\log D_{7.4}=0.85 \pm 0.08$ (ref. 27) and a $\mathrm{p} K_{\mathrm{a}} \leq 11\left(\mathrm{p} K_{1}=3.92\right.$ and $\left.\mathrm{p} K_{2}=10.78\right) .{ }^{28}$ However, as the pyridine $\mathrm{p} K_{1}=3.92$ is quite low, we hypothesized that Triapine might only be partially protonated inside the liposomal core. Hence, two additional novel Triapine derivatives were synthesized (Scheme 2) containing a short lipophilic tail as well as a weak base amine to introduce an additional protonatable moiety in order to achieve properties more comparable to doxorubicin.

\section{Synthesis and characterization of Triapine derivatives}

The Triapine derivatives were synthesized in multiple steps as depicted in Scheme 2. The first step for the preparation of 2 included tert-butyloxycarbonyl (BOC) protection of one $\mathrm{NH}_{2}$

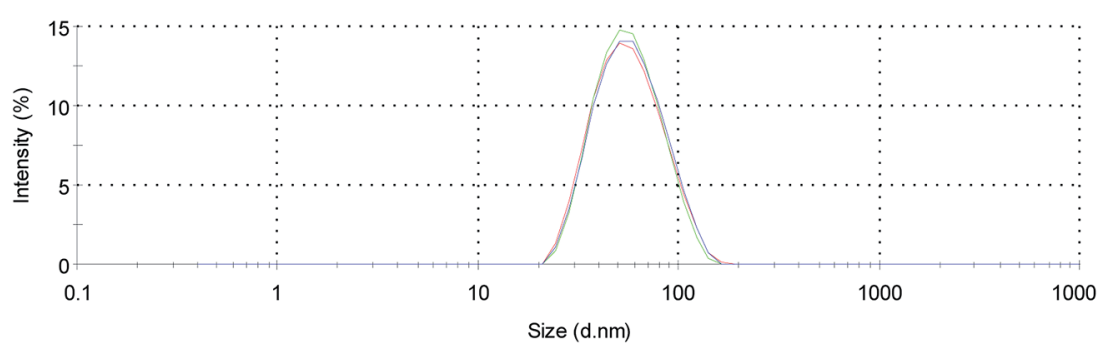

Fig. 1 Size distribution of LP-2 measured by dynamic light scattering 


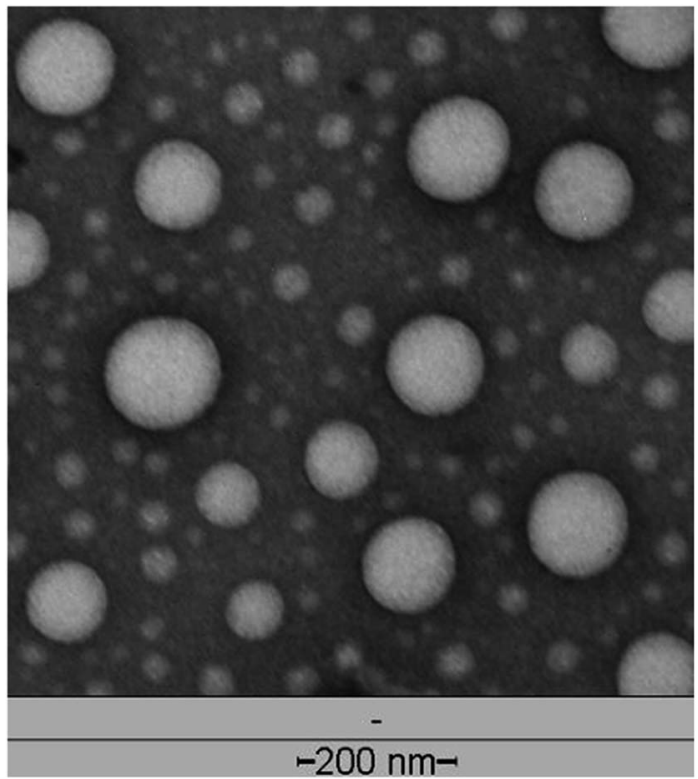

Fig. 2 Transmission electron microscopy (TEM) image of LP-2, negatively stained with $2.5 \%$ gadolinium acetate solution.

group (certainly not necessary in case of 1). Further on, both compounds were prepared according to the same strategy. The respective thiosemicarbazides were obtained by reaction of the amines with $\mathrm{CS}_{2}$, followed by treatment with $\mathrm{CH}_{3} \mathrm{I}$ and displacement of the $S$-methyl group by hydrazine hydrate at $90{ }^{\circ} \mathrm{C}$ in ethanol. Subsequent condensation with the protected 3-amino-2-pyridine carboxaldehyde and acidic deprotection, led to the desired thiosemicarbazones $\mathbf{1}$ and 2. The compounds were characterized by ${ }^{1} \mathrm{H}-\mathrm{NMR},{ }^{13} \mathrm{C}-\mathrm{NMR}$, as well as elemental analysis (see Experimental section).

\section{Liposome preparation and characterization}

The lipid composition of the liposomes was chosen in accordance to Doxil ${ }^{17}$ using DSPC/CHOL/mPEG2000-DSPE in molar ratios of $56: 39: 5$ (DSPC $=1$,2-distearoyl-sn-glycero-3-phosphocholine; CHOL = cholesterol; DSPE-mPEG(2000) = 1,2-distearoyl-sn-glycero-3-phosphoethanolamine- $N$-[methoxy(polyethylene glycol)-2000]). Prior to drug loading, the liposomes were prepared by hydrating a thin lipid film with a $0.3 \mathrm{M}\left(\mathrm{NH}_{4}\right)_{2} \mathrm{SO}_{4}$ solution and reducing the size by sonication. The remote loading of Triapine, 1 and 2 was performed by mixing the drug with the liposomes for $1.5 \mathrm{~h}$ at $65{ }^{\circ} \mathrm{C}$. Afterwards unloaded drug was removed by size exclusion chromatography (Sephadex G50).

The obtained liposomes were characterized by their size and morphology, PDI, EE, reproducibility as well as their size stability (Table 1). All liposomes had an average size of $50 \pm 2$ $\mathrm{nm}$ and a PDI $<0.15$ indicating a narrow size distribution (Fig. 1). The zeta potential for all liposomes was measured at $\mathrm{pH}$ 7.4 with a charge close to neutral $(\xi=0 \pm 1 \mathrm{mV})$. Furthermore, they were highly reproducible and stable in size for at least 100 days. In addition, DLS measurements revealed no changes in size after incubation of the liposomes at $37^{\circ} \mathrm{C}$ for $24 \mathrm{~h}$.

Negative stain transmission electron microscopy (TEM) measurements were carried out to investigate the morphology of the liposomes. Fig. 2 shows a representative micrograph of LP-2, revealing that the liposomes have a spherical shape and confirming the size distribution measured by DLS.

Overall, the EE of $19 \pm 9 \%$ was very low for Triapine-loaded liposomes (LP-Triapine) and varied distinctly. In comparison, liposomes of $\mathbf{1}$ and $\mathbf{2}$ reached twice the drug content of LP-Triapine with $\sim 50 \%$ encapsulation.

\section{Drug release from the liposomes}

The drug release profile of the three thiosemicarbazone-loaded liposomes was investigated at $37{ }^{\circ} \mathrm{C}$ for $72 \mathrm{~h}$ (Fig. 3). For LP-Triapine, a fast burst release with more than $80 \%$ of free Triapine within the first hour was observed (Fig. 3B). For LP-1, the release was distinctly slower compared to LP-Triapine. However, still $\sim 40 \%$ of the free drug was released after one hour. This trend continued with $\sim 80 \%$ release after 48 h. In contrast, LP-2 showed controlled release behavior for more than one day without any critical burst release and less than $30 \%$ of free drug after $24 \mathrm{~h}$.

To determine the in vitro release kinetics of the drugs from the liposomes, zero order, first order, and Higuchi kinetic models were applied to the obtained profiles. ${ }^{29}$ Statistical evaluation showed that LP-Triapine followed a dissolution release kinetic of the first order (with $r^{2}$ values of 0.92), while LP-2 was best explained by the Higuchi model (with $r^{2}=0.98$ ), which is
A

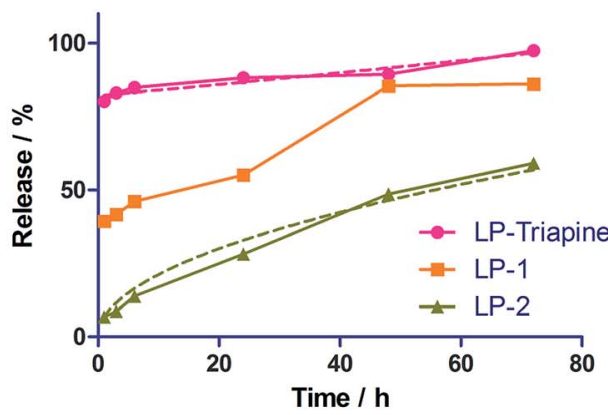

B

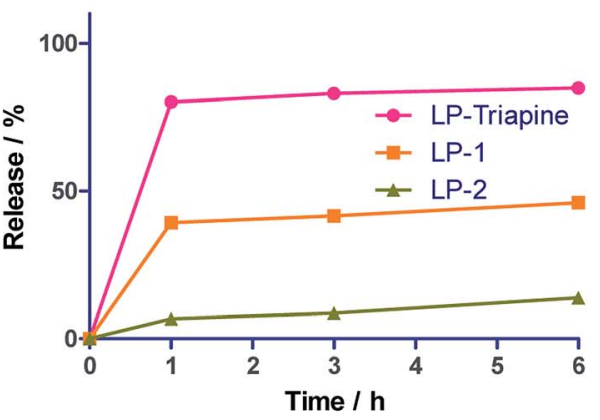

Fig. 3 In vitro release profiles of LP-Triapine, LP-1 and LP-2. (A) Over $72 \mathrm{~h}$ with the respective best fitting release model (highest $r^{2}$ value) is shown with a dashed line: first order model in case of LP-Triapine and Higuchi model in case of LP-2. (B) Zoom of the release data within the first 6 hours. 
Table $2 \quad I C_{50}$ values of free thiosemicarbazones and their liposomal (LP) formulations

\begin{tabular}{lllll}
\hline & $\mathrm{IC}_{50}(\mu \mathrm{M}) \pm \mathrm{SD}(\mu \mathrm{M})$ & & \\
\cline { 2 - 5 } & \multicolumn{1}{c}{$\mathrm{SW} 480$} & & \multicolumn{1}{c}{$\mathrm{A} 2780$} & \\
\hline Triapine & $0.7 \pm 0.02$ & 0.7-Fold & $0.6 \pm 0.01$ & 0.7-Fold \\
LP-Triapine & $0.5 \pm 0.03$ & & $0.4 \pm 0.01$ & \\
$\mathbf{1}$ & $8.2 \pm 0.30$ & 1-Fold & $7.2 \pm 0.09$ & 0.9-Fold \\
LP-1 & $8.2 \pm 0.41$ & & $6.5 \pm 0.22$ & \\
$\mathbf{2}$ & $2.7 \pm 0.16$ & 10.2-Fold & $2.5 \pm 0.16$ & 12-Fold \\
LP-2 & $27.6 \pm 7.75$ & & $29.5 \pm 5.25$ & \\
& & & &
\end{tabular}

indicative for continuous drug release by diffusion..$^{30}$ None of the tested kinetic models were suitable for the description of LP-1.

Overall, this indicates that comparable to the polymeric nanoparticles, there was no stable entrapment of Triapine inside the liposomes. There are two possible explanations for this observation. On the one hand, as already mentioned above, Triapine is characterized by a rather low pyridine $\mathrm{p} K_{1}$, which might result in insufficient protonation of the drug at the $\mathrm{pH}$ of $\sim 5$ inside the liposomes. Therefore, the drug might not be effectively trapped and, consequently, still able to pass the lipid membrane. ${ }^{26}$ On the other hand, our mathematical modelling indicated that LP-Triapine followed a dissolution release kinetic of first order. This suggests that Triapine is not encapsulated inside but just adsorbed to the surface of the liposomes ${ }^{31}$ due to the absence of significant drug-lipid interactions. ${ }^{32}$

In contrast to Triapine, 2 was successfully and stably encapsulated inside the liposomes. The respective drug release kinetic followed the Higuchi model (burst release followed by sustained release), which can be explained by part of the drug adsorbed to the shallow surface, with most of the drug encapsulated inside the aqueous core. ${ }^{33}$ This enhanced entrapment efficacy of 2 in comparison to Triapine is very likely linked to the introduction of an additional protonatable moiety into the thiosemicarbazone molecule, which results in better stabilization of the drug inside the liposome. In general, nanoformulations following such a diffusion-controlled release kinetic can be considered of sufficient stability for subsequent testing in vivo. ${ }^{31,33}$
Cytotoxicity and cellular drug uptake of thiosemicarbazoneloaded liposomes against human cancer cells

As a next step, the growth inhibitory effects of the novel liposomes in comparison to the free drugs were studied by MTT assays in SW480 and A2780 cells (Table 2 and Fig. 4). Noteworthy, due to their PEGylation, our liposomes can be considered as so-called "stealth liposomes", as the PEGylated surface is known to hamper endocytic uptake via macrophages. Consequently, this kind of liposome is usually characterized by a distinctly reduced activity in cell culture compared to the free drug. ${ }^{34}$ In good agreement with our drug release data, neither LP-Triapine nor LP-1 showed any significant difference compared to the free drug. In contrast, LP-2 showed a more than 10-fold lower cytotoxicity in SW480 and 12-fold lower activity in A2780 cells indicating a stable liposomal drug formulation. Therefore, Triapine as well as $\mathbf{1}$ did not have sufficient drug loading stability for biological use, since the therapeutic benefits of liposomal formulations depend on the ability to retain the drug in the carrier and deliver it to the diseased site. ${ }^{19}$ Consequently, only LP-2 was chosen for further investigations, based on its loading capability, enhanced release characteristics as well as favorable decrease in cytotoxicity.

To evaluate whether there is any active or passive uptake of LP-2 into cancer cells, we synthesized fluorescence-labeled liposomes loaded with 2 (NBD-LP-2) using 1\% of 1,2-distearoyl-sn-glycero-3-phosphoethanolamine- $\mathrm{N}$-(7-nitro-2-1,3-benzoxadiazol-4-yl) (NBD-DSPE). In accordance with the PEGylated nature of our liposomes, cellular uptake of NBD-LP-2 was, in general, very low. Consequently, after one hour of incubation, NBD liposomes were detectable only by the very sensitive flow cytometry (Fig. 5A) but not by fluorescence microscopy where longer incubation time (up to $18 \mathrm{~h}$ ) was necessary to allow sufficient drug uptake for detection (Fig. 5B). However, the detected fluorescence (in flow cytometry) was significantly reduced (to $\sim 50 \%$ ) at $4{ }^{\circ} \mathrm{C}$ (in comparison to $37^{\circ} \mathrm{C}$ ), indicating some active uptake of the liposomes via endocytosis. This is also in line with the vesicular localization of the fluorescence after 24 $\mathrm{h}$ of drug incubation (Fig. 5C).

The reason for a delayed uptake of NBD-LP-2 might be the PEGylation of the liposomal surface. PEGylation is used to
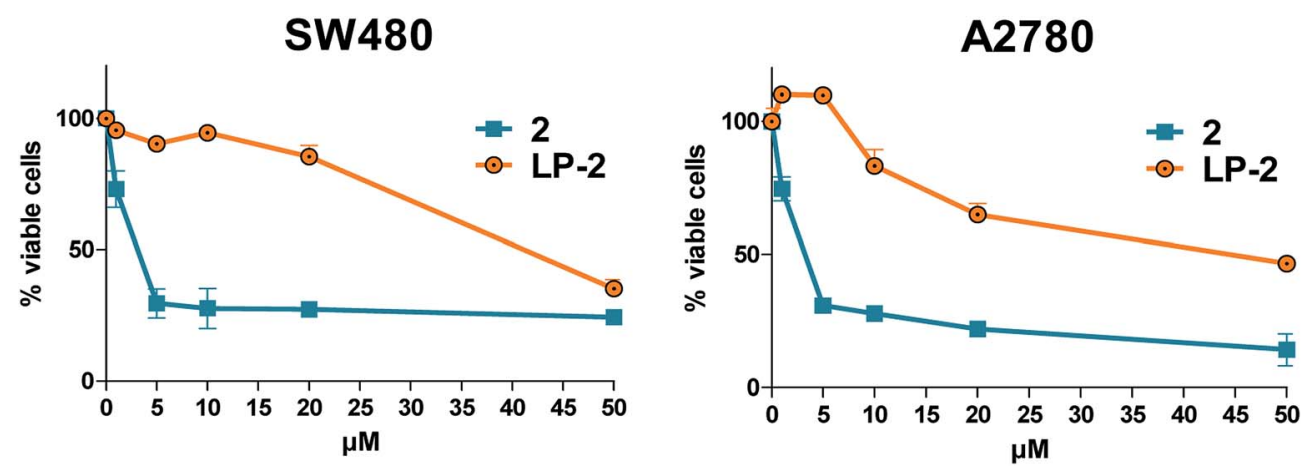

Fig. 4 Representative dose-response curves of SW480 and A2780 cells treated with 2 and LP-2. Cell viability was determined by MTT assay after $72 \mathrm{~h}$ treatment. Values given are means \pm SD of one representative experiment performed in triplicate. 


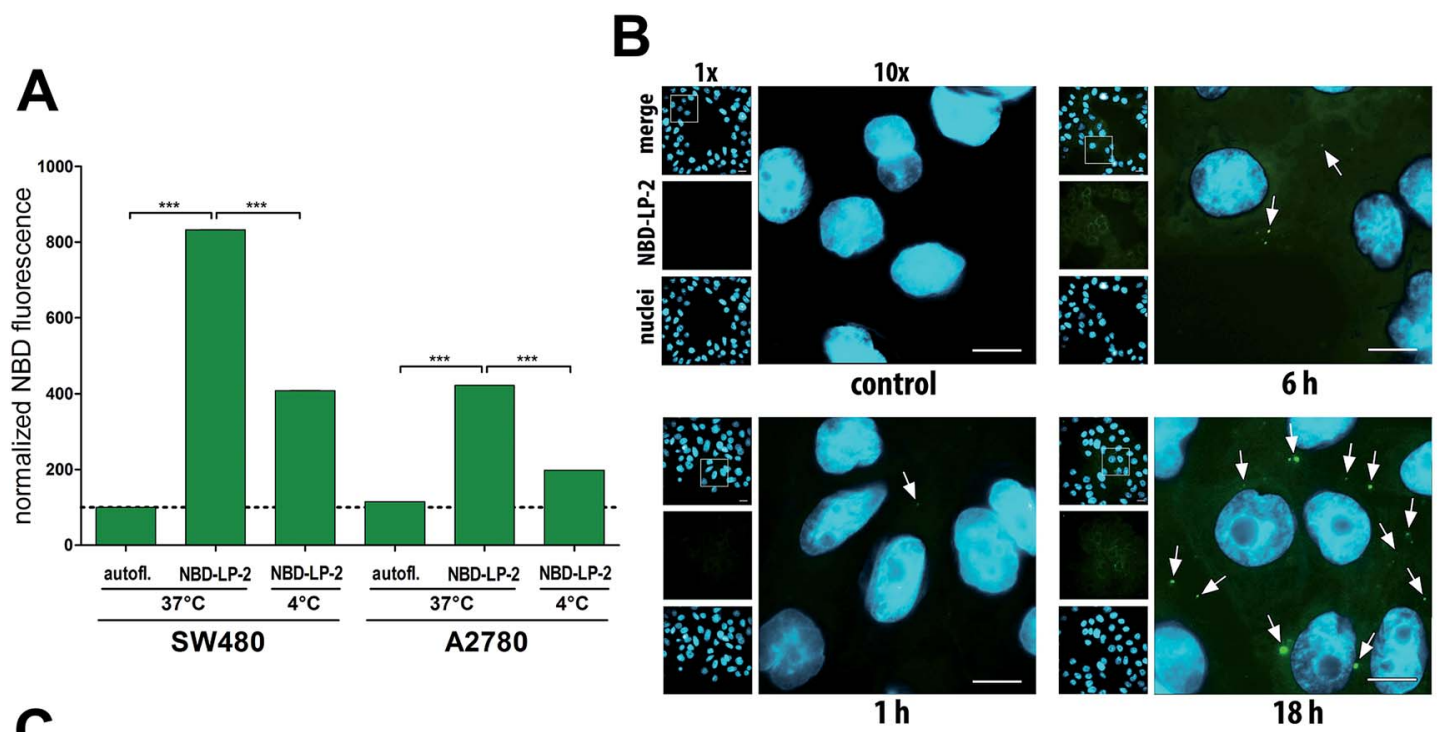

C

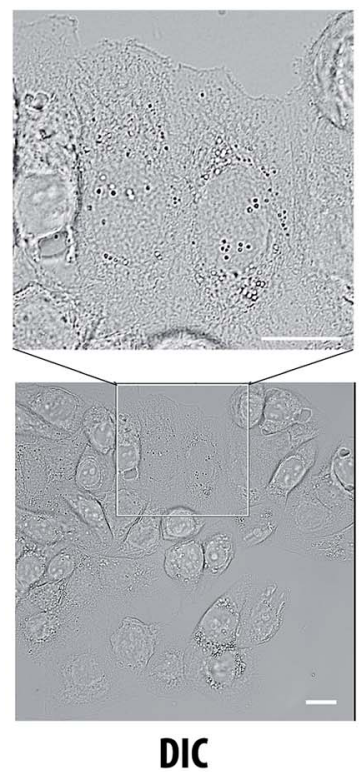

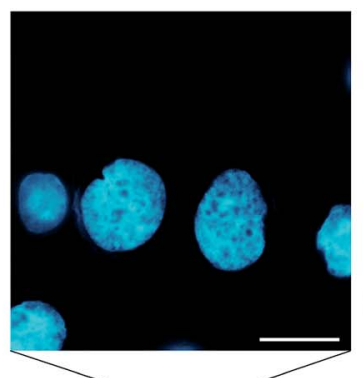

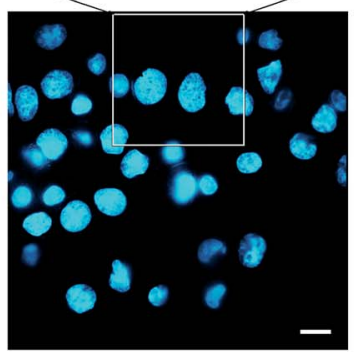

nuclei
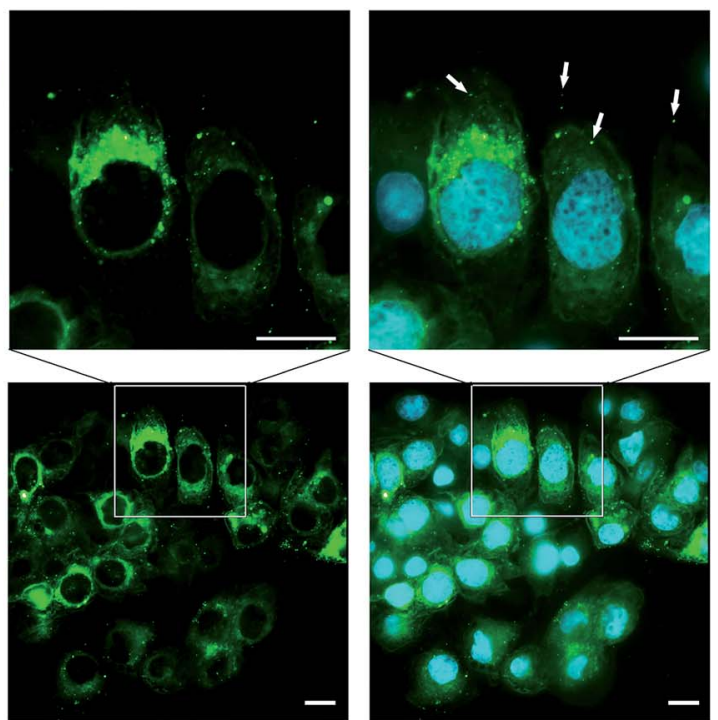

NBD-LP-2

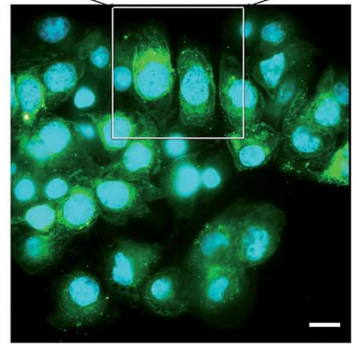

merge

Fig. 5 Cellular uptake of fluorescence (NBD)-labeled LP-2. (A) SW480 and A2780 cells were treated with NBD-LP-2 (8 $\mu$ M referred to NBD) for $1 \mathrm{~h}$ at $37^{\circ} \mathrm{C}$ or $4{ }^{\circ} \mathrm{C}$, washed once with PBS and analyzed by flow cytometry for fluorescence intensity. *** $p<0.001$ one-way ANOVA with Bonferroni posttest. (B) Fluorescence microscopy of time-dependent liposome uptake in SW480 cells treated with NBD-LP-2 (33 $\mu$ M referred to NBD) for 1,6 and $18 \mathrm{~h}$ at $37^{\circ} \mathrm{C}$. (C) Fluorescence microscopy of long-term liposomal uptake in SW480 cells after treatment with NBD-LP-2 $(33 \mu \mathrm{M})$ for $24 \mathrm{~h}$ at $37{ }^{\circ} \mathrm{C}$. After fixation with $4 \%$ paraformaldehyde, nuclei were stained with DAPI. Micrographs were taken with a fluorescence microscope in differential interference contrast (DIC), green (liposomes) and UV (nuclei) channels. Size bar $=20 \mu \mathrm{m}$.

increase the stability of the liposomes and prolong the circulation in the bloodstream but also minimize the opsonization and thus, decrease the immediate uptake by macrophages. ${ }^{35}$ Nevertheless, partial uptake of PEGylated liposomes by cancer cells was described as well. ${ }^{36}$

\section{Anticancer activity of LP-2}

As a next step, tolerability and anticancer activity of LP-2 was evaluated in comparison to unbound 2 in CT-26-bearing Balb/c mice. As shown in Fig. 6A, all treatment schemes were well tolerated with no significant change in body weight (tested by 2way ANOVA). With regard to the anticancer activity, 2 was significantly but only transiently reducing the tumor growth, when calculated until the last day of treatment (day 14; $p<0.001$ by 2 -way ANOVA; Fig. 6B). Consequently, treatment with 2 had no impact on overall survival of the treated mice (Fig. 6C). Interestingly, LP-2 had less impact than 2 on tumor growth during the two weeks of therapy. However, half of the animals reacted with tumor stabilization or shrinkage after some lag time (Fig. 6B indicated by small black arrows). This indicates that the nanoformulation LP-2 either needs some time for accumulation of sufficient intratumoral drug levels or for sufficient drug release from the liposomes. Noteworthy, it is well known that Triapine is characterized by a very low plasma- 

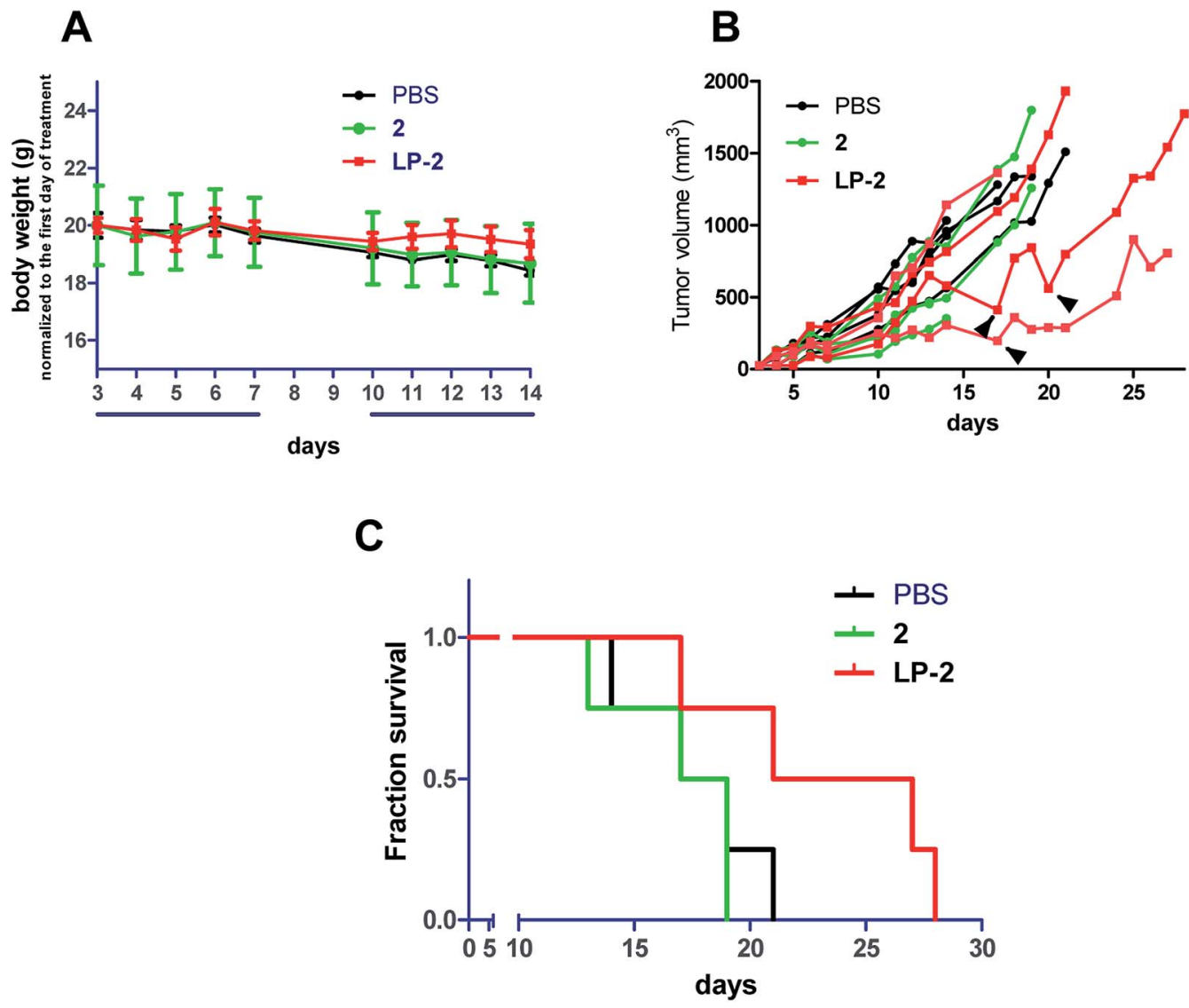

Fig. 6 Tolerability and anticancer activity of LP-2 vs. 2 in vivo. Murine CT-26 cells $\left(5 \times 10^{5}\right)$ were injected subcutaneously into the right flank of female Balb/c mice ( $n=4$ per group). Animals were treated with the drug intravenously ( $4 \mathrm{mg} \mathrm{kg}^{-1}$ in PBS) on day 3-7 and $10-14$. (A) Body weight during therapy; (B) tumor size of the individual mice was assessed regularly by caliper measurement. Tumor volumes were calculated by using the formula: length $\times$ width $^{2} / 2$. Days of tumor regression are indicated by black arrows. (C) Plot of the overall survival.

half life (less than one hour ${ }^{12,37,38}$ ), which together with the rather transient nature of its mode of action (stop of DNA synthesis), probably explains its lack of activity in clinical trials against solid cancer types. We have recently shown that Triapine has also strong anticancer activity against CT-26 isografts. ${ }^{12}$ However, already a therapy break of one day was sufficient to allow significant regrowth of the tumors. Due to the lack of impact of unbound 2 on the overall survival of CT-26bearing mice, it can be expected that also this thiosemicarbazone has only a transient activity. Consequently, our experiments indicate that liposomal encapsulation indeed is a promising strategy to overcome the limitations observed in therapy with thiosemicarbazones.

\section{Methemoglobin formation}

A common side effect in clinical phase I and II trials with Triapine is the oxidation of oxyhemoglobin $\left(\mathrm{HbO}_{2}\right)$ to methemoglobin (metHb), the so-called methemoglobinemia. ${ }^{39}$ The occurrence of this oxidation reaction is explained by the formation of $\mathrm{Fe}^{\mathrm{III}}$ complexes of Triapine in the blood stream and subsequent oxidation of hemoglobin. ${ }^{40}$ This prompted us to study, on the one hand, if also 2 promotes formation of
metHb in the presence of $\mathrm{Fe}^{\mathrm{III}}$ and, on the other hand, whether liposomal formulations of 2 are able to prevent this reaction. Hence, 2 and $\mathbf{L P}-2$ were incubated with $\mathrm{Fe}\left(\mathrm{NO}_{3}\right)_{3}(2: 1$ ratio) for $20 \mathrm{~min}$ and subsequently the reaction of $\mathrm{HbO}_{2}$ was monitored by UV-Vis spectroscopy (Fig. 7). In case of the free compound 2 , a distinct decrease in the absorption of the typical $\mathrm{HbO}_{2}$ bands at 577 and $539 \mathrm{~nm}$ accompanied with an increase at 404 and 630 $\mathrm{nm}$ and a hypsochromic shift of the band at $404 \mathrm{~nm}$ were observed after incubation with $\mathrm{Fe}^{\mathrm{III}}$ (Fig. 7A and C), indicating. the fast formation of metHb. ${ }^{41,42}$ Quantitative evaluation revealed that $60 \pm 3 \%$ of the total $\mathrm{Hb}$ are oxidized to metHb. Noteworthy, after incubation with $\mathrm{Fe}^{\mathrm{III}}$, LP-2 shows only very small changes in the intensity of the $\mathrm{HbO}_{2}$ bands indicating negligible formation of metHb $(5 \pm 1 \%$ of total $\mathrm{Hb}$ see Fig. $7 \mathrm{~B}$ and $\mathrm{C})$. This suggests that the liposomal formulation either inhibits the formation of the redox-active $\mathrm{Fe}^{\mathrm{III}}$ complex or sterically prevents interaction of 2 with $\mathrm{HbO}_{2}$ due to the lipid barrier. 2 without $\mathrm{Fe}\left(\mathrm{NO}_{3}\right)_{3}$ had a much smaller effect on the $\mathrm{HbO}_{2}$ spectra (Fig. S5†).

To assess the metHb generation of 2 and LP-2 in vivo, mice were treated with a single intravenous injection of 2 or LP-2 (compared to an untreated control) and blood was collected 
A

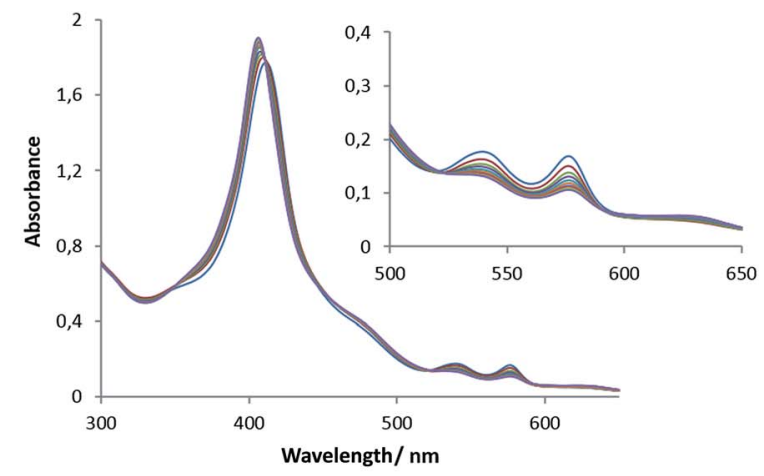

B

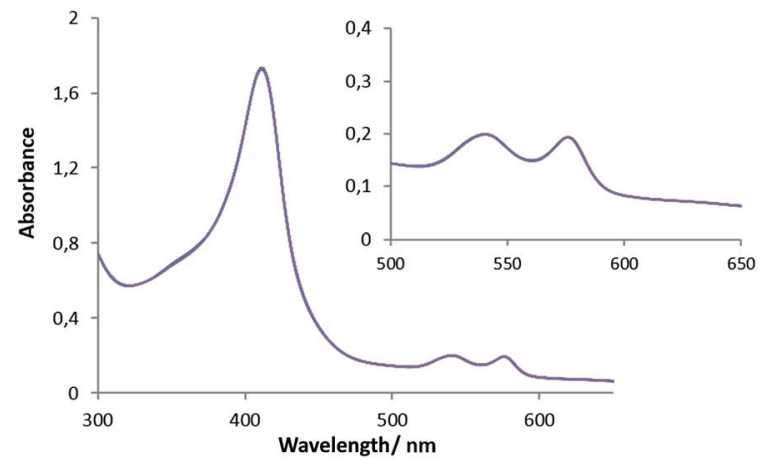

C

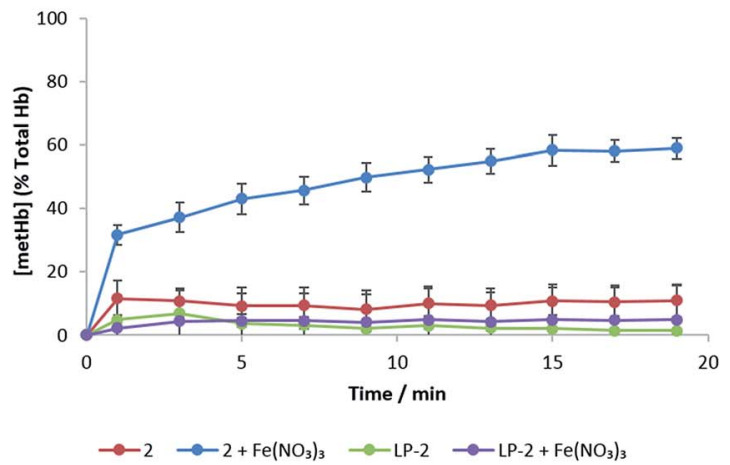

Fig. 7 Time resolved UV-Vis spectral changes of the reaction between human $\mathrm{HbO}_{2}$ and (A) 2 in the presence of Fe ${ }^{\text {III }}$ as well as (B) LP-2 in the presence of $\mathrm{Fe}^{\mathrm{III}}$ and $(\mathrm{C})$ quantitative illustration of the metHb formation in the presence and absence of Fe ${ }^{I I I}$ (results are mean \pm SD (three experiments)).

after $60 \mathrm{~min}$. The results showed the same tendency as observed in the in vitro assay (Fig. S6 $\dagger$ ), however the differences were not significant, most likely due to the limited drug concentration of the liposomal formulation, which did not allow further increase of the applied dose of both 2 and LP-2.

\section{Conclusion}

The missing activity of Triapine against solid cancer types is believed to rely on a short plasma half-time, a rapid elimination and resulting insufficient drug levels in the solid tumor tissue. Accordingly, drug delivery systems based on nanoparticles offer the opportunity to overcome these limitations by enhancement of plasma half-time and increased drug accumulation in the malignant tissue due to the so called EPR-effect. Overall, for a successful clinical development of nanocarriers, several parameters have to be considered. Besides the size, EE and reproducibility, a balanced drug release profile has a high impact on the therapeutic effectiveness, as the drug is, on the one hand, inactive while encapsulated and, on the other hand, rapidly excreted when released too fast. In view of that, this study aimed to develop a new nanoparticulate formulation of Triapine with improved delivery properties for in vivo applications.

Therefore, the first Triapine-loaded polymeric nanoparticles as well as remotely loaded liposomes were successfully prepared. However, in both cases, a fast burst release was observed, which also resulted in similar cytotoxic activity compared to the free drug, which might explain, why there are no literature reports on Triapine-loaded nanoparticles so far. Consequently, two novel Triapine derivatives were synthesized and, for compound 2, a stable liposomal formulation with desired continuous drug release was achieved. By this approach, not only a significant increase in survival, but also complete prevention of methemoglobin formation, a frequently observed side effect of thiosemicarbazone treatment in clinical trials, was accomplished. In conclusion, our study shows that nanoformulations of thiosemicarbazones are a promising strategy to improve the performance of thiosemicarbazones in clinical evaluations.

\section{Experimental section}

\section{Chemicals}

PLA (MW 75 000-120 000), PLGA RG 503H (MW 24 000-38 000; Sigma Aldrich), Tween 80 (MW 1310; Fisher Scientific, Austria) and methanol (HPLC grade, Fisher Scientific, Austria) were used as supplied. 1,2-Distearoyl-sn-glycero-3-phosphocholine (DSPC), cholesterol, 1,2-distearoyl-sn-glycero-3-phosphoethanolamine$N$-[methoxy(polyethylene glycol)-2000] (ammonium salt) (DSPEmPEG(2000)) and 1,2-distearoyl-sn-glycero-3-phosphoethanolamine- $N$-(7-nitro-2-1,3-benzoxadiazol-4-yl) (ammonium salt) (NBD-DSPE) were purchased from Avanti Polar Lipids Inc. (Alabaster, AL). Triapine was synthesized according to literature procedures. ${ }^{43}$ Human hemoglobin was purchased from Sigma Aldrich. MilliQ water was obtained from a Millipore Advantage A10 185 UV Ultrapure Water System (18.2 M 2 ; Molsheim, France). All other chemicals were of analytical grade and used without further purification.

\section{Preparation of drug-loaded nanoparticles}

For preparation of the nanoparticles the nanoprecipitation method was used. ${ }^{27}$ Therefore, $40 \mathrm{mg}$ of PLA $(\sim 0.44 \mu \mathrm{mol})$ or PLGA $(\sim 1.3 \mu \mathrm{mol})$ and $4 \mathrm{mg}$ Triapine were dissolved in $3.9 \mathrm{~mL}$ acetone and $0.1 \mathrm{~mL}$ dichloromethane. This solution was poured under stirring into $10 \mathrm{~mL}$ of a $0.25 \%(\mathrm{w} / \mathrm{v})$ aqueous phase of Tween 80 and stirred for $30 \mathrm{~min}$ at rt. The organic solvents were evaporated under reduced pressure at $35{ }^{\circ} \mathrm{C}$. Free Triapine was removed by dialysis against water (MWCO: $3.5 \mathrm{kDa}$ ) for $24 \mathrm{~h}$ and the volume was adjusted under reduced pressure to $1 \mathrm{~mL}$. The 
nanoparticles were stored at $4{ }^{\circ} \mathrm{C}$. Drug-free nanoparticles were prepared by the same procedure.

\section{Synthesis of compound 1 and 2}

tert-Butyl(4-aminobutyl)carbamate (2a). Di-tert-butyl dicarbonate $(9.6 \mathrm{~g}, 44 \mathrm{mmol})$ was dissolved in $50 \mathrm{~mL}$ chloroform and slowly added to a solution of 1,4-diaminobutane $(22 \mathrm{~mL}$, $220 \mathrm{mmol}$ ) in $150 \mathrm{~mL}$ chloroform at $0{ }^{\circ} \mathrm{C}$. The solution was stirred at rt overnight. The precipitate was filtered off and the solvent was removed under reduced pressure. The residue was dissolved in $400 \mathrm{~mL}$ of EtOAc and extracted with $\mathrm{H}_{2} \mathrm{O}(2 \times$ $60 \mathrm{~mL})$ and brine $(60 \mathrm{~mL})$. The organic layer was dried over $\mathrm{Na}_{2} \mathrm{SO}_{4}$, filtered and evaporated under reduced pressure and dried in vacuo. Yield: $5.95 \mathrm{~g}(72 \%) .{ }^{1} \mathrm{H}$ NMR (DMSO- $d_{6}, 500.10$ $\mathrm{MHz}): \delta=6.77(\mathrm{t}, 1 \mathrm{H}, \mathrm{NHC}=\mathrm{O}), 2.87\left(\mathrm{q}, 2 \mathrm{H}, \mathrm{NHCH}_{2}\left(\mathrm{CH}_{2}\right)_{2}\right)$, $2.49\left(2 \mathrm{H}, \mathrm{CH}_{2} \mathrm{NH}_{2}\right.$, partially below the DMSO signal), 1.37-1.27 $\left(\mathrm{m}, 13 \mathrm{H}, \mathrm{C}\left(\mathrm{CH}_{3}\right)_{3}\right.$ and $\left.\mathrm{CH}_{2}\left(\mathrm{CH}_{2}\right)_{2} \mathrm{CH}_{2}\right) \mathrm{ppm}$.

\section{General procedure for the synthesis of $1 b$ and $2 b$}

The amine and 1 eq. of $\mathrm{Et}_{3} \mathrm{~N}$ were dissolved in $\mathrm{EtOH}$ and 1 eq. of $\mathrm{CS}_{2}$ in EtOH was added drop-wise. The reaction mixture was stirred at rt for $1.5 \mathrm{~h}$, treated with 1 eq. of $\mathrm{CH}_{3} \mathrm{I}$ and further stirred for $1.5 \mathrm{~h}$. The solvent was removed under reduced pressure. EtOAc was added and the solution was extracted with $1 \mathrm{M} \mathrm{HCl}$, saturated $\mathrm{NaHCO}_{3}$ and water. The organic layer was dried over $\mathrm{Na}_{2} \mathrm{SO}_{4}$, filtered and evaporated under reduced pressure and dried in vacuo.

Methyl (2-(dimethylamino)ethyl)carbamodithioate (1b). Dimethylethylenediamine $(3.28 \mathrm{~g}, 37.0 \mathrm{mmol})$ and $\mathrm{Et}_{3} \mathrm{~N}(5.09$ $\mathrm{mL}, 37.0 \mathrm{mmol})$ in EtOH $(80 \mathrm{~mL}), \mathrm{CS}_{2}(2.21 \mathrm{~mL}, 37.0 \mathrm{mmol})$ in EtOH $(5 \mathrm{~mL}), \mathrm{CH}_{3} \mathrm{I}(2.28 \mathrm{~mL}, 37.0 \mathrm{mmol})$, EtOAc $(60 \mathrm{~mL}), 1 \mathrm{M}$ $\mathrm{HCl}(50 \mathrm{~mL})$, saturated $\mathrm{NaHCO}_{3}(50 \mathrm{~mL})$ and water $(50 \mathrm{~mL})$. Yield: $3.5 \mathrm{~g}(42 \%)$.

${ }^{1} \mathrm{H}$ NMR (DMSO- $\left.d_{6}, 500.10 \mathrm{MHz}\right): \delta=9.80(\mathrm{bs}, 1 \mathrm{H}, \mathrm{NHC}=\mathrm{S}$ ), $3.69\left(\mathrm{t},{ }^{3} \mathrm{~J}=7 \mathrm{~Hz}, 2 \mathrm{H}, \mathrm{NHCH}_{2}\right), 2.52\left(2 \mathrm{H}, \mathrm{CH}_{2} \mathrm{~N}\left(\mathrm{CH}_{3}\right)_{2}, 3 \mathrm{H}, \mathrm{CH}_{3} \mathrm{~S}\right.$, partially below the DMSO signal), $2.20\left(\mathrm{~s}, 6 \mathrm{H}, \mathrm{N}\left(\mathrm{CH}_{3}\right)_{2}\right)$, ppm.

tert-Butyl (4-(((methylthio)carbonothioyl)amino)butyl) carbamate (2b). tert-Butyl (4-aminobutyl)carbamate (2a; $5.85 \mathrm{~g}$, $31.0 \mathrm{mmol})$ and $\mathrm{Et}_{3} \mathrm{~N}(4.36 \mathrm{~mL}, 31.0 \mathrm{mmol})$ in $\mathrm{EtOH}(98 \mathrm{~mL})$, $\mathrm{CS}_{2}(1.87 \mathrm{~mL}, 31.0 \mathrm{mmol})$ in EtOH $(7 \mathrm{~mL}), \mathrm{CH}_{3} \mathrm{I}(1.93 \mathrm{~mL}, 31.0$ mmol), EtOAc $(50 \mathrm{~mL}), 1 \mathrm{M} \mathrm{HCl}(40 \mathrm{~mL})$, saturated $\mathrm{NaHCO}_{3}$ (40 mL) and water (40 mL). Yield: $3.6 \mathrm{~g}(42 \%) .{ }^{1} \mathrm{H}$ NMR (DMSO$\left.d_{6}, 500.10 \mathrm{MHz}\right): \delta=9.88\left(\mathrm{t},{ }^{3} J=5 \mathrm{~Hz}, 1 \mathrm{H}, \mathrm{NHC}=\mathrm{S}\right), 6.82-6.73$ $(\mathrm{m}, 1 \mathrm{H}, \mathrm{NHC}=\mathrm{O}), 3.60-3.52$ and $2.95-2.88\left(\mathrm{~m}, 4 \mathrm{H}, \mathrm{CH}_{2}\left(\mathrm{CH}_{2}\right)_{2^{-}}\right.$ $\left.\mathrm{CH}_{2}\right), 2.52\left(3 \mathrm{H}, \mathrm{CH}_{3} \mathrm{~S}\right.$, partially below the DMSO signal), 1.58$1.50\left(\mathrm{~m}, 2 \mathrm{H}, \mathrm{CH}_{2}\right), 1.42-1.32\left(\mathrm{~m}, 11 \mathrm{H}, \mathrm{C}\left(\mathrm{CH}_{3}\right)_{3}\right.$ and $\left.\mathrm{CH}_{2}\right) \mathrm{ppm}$.

$\mathrm{N}$-(2-(Dimethylamino)ethyl)hydrazinecarbothioamide (1c). To a solution of $\mathbf{1 b}(1.00 \mathrm{~g}, 5.6 \mathrm{mmol})$ in $\mathrm{EtOH}(10 \mathrm{~mL})$, hydrazine hydrate $(0.440 \mathrm{~mL}, 9.04 \mathrm{mmol})$ was added and the reaction mixture was refluxed at $90{ }^{\circ} \mathrm{C}$ for $4.5 \mathrm{~h}$. The solvent was removed under reduced pressure. The residue was dried in vacuo and the solid was filtered and washed with $\mathrm{Et}_{2} \mathrm{O}$. Yield: $0.40 \mathrm{~g}(44 \%) .{ }^{1} \mathrm{H}$ NMR (DMSO- $d_{6}, 500.10 \mathrm{MHz}$ ): $\delta=8.61$ (bs, $1 \mathrm{H}$, $\mathrm{NH}), 7.77(\mathrm{bs}, 1 \mathrm{H}, \mathrm{NH}), 4.43\left(\mathrm{~s}, 2 \mathrm{H}, \mathrm{N} H_{2}\right), 3.50\left(\mathrm{dd}, 2 \mathrm{H},{ }^{3} J_{\mathrm{H}, \mathrm{H}}=\right.$ $\left.12,{ }^{3} J_{\mathrm{H}, \mathrm{H}}=6, \mathrm{NHCH}_{2}\right), 2.37\left(\mathrm{t}, 2 \mathrm{H},{ }^{3} J_{\mathrm{H}, \mathrm{H}}=6, \mathrm{CH}_{2}\right), 2.15(\mathrm{~s}, 6 \mathrm{H}$, $\left.\mathrm{N}\left(\mathrm{CH}_{3}\right)_{2}\right)$ ppm.
tert-Butyl (4-(hydrazinecarbothioamido)butyl)carbamate (2c). To a solution of $2 \mathbf{b}(3.63 \mathrm{~g}, 13.0 \mathrm{mmol})$ in EtOH $(60 \mathrm{~mL})$, hydrazine hydrate $(1.032 \mathrm{~mL}, 21.2 \mathrm{mmol}$ ) was added and the reaction mixture was refluxed at $90{ }^{\circ} \mathrm{C}$ for $4.5 \mathrm{~h}$. The solvent was removed under reduced pressure. $\mathrm{Et}_{2} \mathrm{O}(30 \mathrm{~mL})$ was added and the solution was stored at $4{ }^{\circ} \mathrm{C}$ overnight. The white precipitate was filtered, washed with cold $\mathrm{Et}_{2} \mathrm{O}$ and dried in vacuo. Yield: $2.79 \mathrm{~g}(81 \%) .{ }^{1} \mathrm{H}$ NMR (DMSO- $\left.d_{6}, 500.10 \mathrm{MHz}\right): \delta=8.54(\mathrm{~s}, 1 \mathrm{H}$, $\mathrm{NH}), 7.80(\mathrm{~s}, 1 \mathrm{H}, \mathrm{NH}), 6.79\left(\mathrm{t},{ }^{3} \mathrm{~J}=5 \mathrm{~Hz}, 1 \mathrm{H}, \mathrm{N} H \mathrm{C}=\mathrm{O}\right), 4.43(\mathrm{~s}$, $\left.2 \mathrm{H}, \mathrm{NH}_{2}\right), 3.46-3.39$ and 2.95-2.89 (m, 4H, $\left.\mathrm{CH}_{2}\left(\mathrm{CH}_{2}\right)_{2} \mathrm{CH}_{2}\right)$, 1.52-1.43 (m, 2H, $\left.\mathrm{CH}_{2}\right), 1.43-1.32\left(\mathrm{~m}, 11 \mathrm{H}, \mathrm{C}\left(\mathrm{CH}_{3}\right)_{3}\right.$ and $\left.\mathrm{CH}_{2}\right)$ ppm.

(E)-2-((3-Aminopyridin-2-yl)methylene)- $N$-(2-(dimethylamino) ethyl)-hydrazinecarbothioamide dihydrochloride (1). To a solution of (2-formyl-pyridin-3-yl)-carbamic acid tert-butyl ester ${ }^{43}$ $(0.062 \mathrm{~g}, 0.279 \mathrm{mmol})$ in EtOH $(1 \mathrm{~mL}) 1 \mathrm{c}(0.050 \mathrm{~g}, 0.308 \mathrm{mmol})$, $0.126 \mathrm{~mL}$ concentrated $\mathrm{HCl}$ and $0.467 \mathrm{~mL} \mathrm{H}_{2} \mathrm{O}$ were added. The solution was refluxed for $3 \mathrm{~h}$. The mixture was concentrated to one third, the product was precipitated with $\mathrm{Et}_{2} \mathrm{O}$, filtered and dried in vacuo. Yield: $0.50 \mathrm{~g}(68 \%)$. Elemental analysis for $\mathrm{C}_{11^{-}}$ $\mathrm{H}_{18} \mathrm{~N}_{6} \mathrm{~S} \cdot 2 \mathrm{HCl} \cdot 0.4 \mathrm{H}_{2} \mathrm{O}$ : calcd C 38.12, H 6.05, N 24.25, S 9.25\%; found: C 38.42, H 5.99, N 24.01, S 8.98\%. ${ }^{1} \mathrm{H}$ NMR $\left(\mathrm{D}_{2} \mathrm{O}, 500.10\right.$ $\mathrm{MHz}): \delta=8.29(\mathrm{~s}, 1 \mathrm{H}, H \mathrm{C}=\mathrm{N}), 8.05\left(\mathrm{~d},{ }^{3} J=5.2 \mathrm{~Hz}, 1 \mathrm{H}, H_{\mathrm{py}}\right)$, $7.84\left(\mathrm{~d},{ }^{3} J=9 \mathrm{~Hz}, 1 \mathrm{H}, H_{\mathrm{py}}\right), 7.67\left(\mathrm{dd},{ }^{3} J=9 \mathrm{~Hz},{ }^{4} J=5 \mathrm{~Hz}, 1 \mathrm{H}\right.$, $\left.H_{\text {py }}\right), 4.13\left(\mathrm{t},{ }^{3} J=6 \mathrm{~Hz}, 2 \mathrm{H}, \mathrm{NHCH}_{2}\right), 3.52\left(\mathrm{t},{ }^{3} J=6 \mathrm{~Hz}, 2 \mathrm{H}\right.$, $\left.\mathrm{CH}_{2} \mathrm{~N}\left(\mathrm{CH}_{3}\right)_{2}\right), 3.00\left(\mathrm{~s}, 6 \mathrm{H}, \mathrm{N}\left(\mathrm{CH}_{3}\right)_{2}\right) \mathrm{ppm} .{ }^{13} \mathrm{C} \mathrm{NMR}\left(\mathrm{D}_{2} \mathrm{O}, 125.75\right.$ $\mathrm{MHz}): \delta 180.0(\mathrm{C}=\mathrm{S}), 145.9\left(\mathrm{C}_{\mathrm{q}, \mathrm{py}}\right), 135.4(\mathrm{~N}=C \mathrm{H}), 132.1\left(\mathrm{C}_{\mathrm{py}}\right)$, $131.1\left(\mathrm{C}_{\mathrm{py}}\right), 126.7\left(\mathrm{C}_{\mathrm{py}}\right), 126.3\left(\mathrm{C}_{\mathrm{q}, \mathrm{py}}\right), 56.4\left(\mathrm{CH}_{2}-\mathrm{NH}\right), 43.3$ $\left(\mathrm{N}\left(\mathrm{CH}_{3}\right)_{2}\right), 39.2\left(\mathrm{NH}-\mathrm{CH}_{2}-\right)$ ppm.

(E)- $N$-(4-Aminobutyl)-2-((3-aminopyridin-2-yl)methylene)hydrazine-1-carbothioamide dihydrochloride (2). To a solution of $2 \mathrm{c}$ (0.5 g, $1.9 \mathrm{mmol})$ in EtOH (25 mL) (2-formyl-pyridin-3-yl)carbamic acid tert-butyl ester $^{43}(0.425 \mathrm{~g}, 1.91 \mathrm{mmol})$ was added. The solution was refluxed for $4 \mathrm{~h}$. After cooling to rt and filtration $12 \mathrm{~mL}$ of $\mathrm{H}_{2} \mathrm{O}$ were added and the solution was stored at $4{ }^{\circ} \mathrm{C}$ overnight. The yellow precipitate was filtered off, washed with $\mathrm{H}_{2} \mathrm{O}$ and ice cold iso-propanol and dried in vacuo. For deprotection the precipitate was dissolved in iso-propanol (50 $\mathrm{mL}$ ) at $80{ }^{\circ} \mathrm{C}$ and $0.8 \mathrm{~mL}$ concentrated $\mathrm{HCl}$ was added. The mixture was refluxed for $4 \mathrm{~h}$. After cooling to rt, the precipitate was filtered and washed with ice cold iso-propanol and dried in vacuo. Yield: $0.48 \mathrm{~g}(54 \%)$. Elemental analysis for $\mathrm{C}_{11} \mathrm{H}_{18} \mathrm{~N}_{6}$ $\mathrm{S} \cdot 2 \mathrm{HCl} \cdot 1.1 \mathrm{H}_{2} \mathrm{O}$ : calcd C 36.79, H 6.23; N 23.40, S 8.93\%; found: C 37.15, H 6.12, N 23.06, S 8.87\%. ${ }^{1} \mathrm{H}$ NMR $\left(\mathrm{D}_{2} \mathrm{O}, 500.10 \mathrm{MHz}\right)$ : $\delta=8.22(\mathrm{~s}, 1 \mathrm{H}, H \mathrm{C}=\mathrm{N}), 7.99\left(\mathrm{dd},{ }^{3} J=4 \mathrm{~Hz},{ }^{4} J=1 \mathrm{~Hz}, 1 \mathrm{H}, H_{\mathrm{py}}\right)$, $7.78\left(\mathrm{~d},{ }^{3} J=9 \mathrm{~Hz}, 1 \mathrm{H}, H_{\mathrm{py}}\right), 7.60\left(\mathrm{dd},{ }^{3} J=9 \mathrm{~Hz},{ }^{4} J=5 \mathrm{~Hz}, 1 \mathrm{H}\right.$, $\left.H_{\text {py }}\right), 3.67\left(\mathrm{t},{ }^{3} J=6 \mathrm{~Hz}, 2 \mathrm{H}, \mathrm{NHCH}_{2}\right), 3.01\left(\mathrm{t},{ }^{3} J=7 \mathrm{~Hz}, 2 \mathrm{H}\right.$, $\left.\mathrm{CH}_{2} \mathrm{NH}\right), 1.76-1.66\left(\mathrm{~m}, 4 \mathrm{H}, \mathrm{CH}_{2}\left(\mathrm{CH}_{2}\right)_{2} \mathrm{CH}_{2}\right)$ ppm. ${ }^{13} \mathrm{C} \mathrm{NMR}$ $\left(\mathrm{D}_{2} \mathrm{O}, 125.75 \mathrm{MHz}\right): \delta 176.5(C=\mathrm{S}), 145.7\left(\mathrm{C}_{\mathrm{q}, \mathrm{py}}\right), 134.5(\mathrm{CH}=\mathrm{N})$, $132.1\left(\mathrm{C}_{\mathrm{py}}\right), 131.1\left(\mathrm{C}_{\mathrm{py}}\right), 126.6\left(\mathrm{C}_{\mathrm{py}}\right), 126.5\left(\mathrm{C}_{\mathrm{q}, \mathrm{py}}\right), 43.6\left(\mathrm{NHCH}_{2}\right)$, $39.2\left(\mathrm{CH}_{2} \mathrm{NH}_{2}\right), 25.4\left(\left(-\mathrm{CH}_{2}-\right)\right), 24.0\left(\left(-\mathrm{CH}_{2}-\right)\right) \mathrm{ppm}$.

\section{Preparation of drug-loaded liposomes}

Liposomes were prepared using the remote loading approach. ${ }^{26}$ Briefly, $20 \mathrm{mg}$ DSPC, $6.5 \mathrm{mg}$ PEG-2000PE and $7.2 \mathrm{mg}$ cholesterol were dissolved in $5 \mathrm{~mL} \mathrm{CHCl} / \mathrm{MeOH}(4: 1, \mathrm{v} / \mathrm{v})$ and stirred for 
$1.5 \mathrm{~h}$ at $65^{\circ} \mathrm{C}$. The solvent was removed under reduced pressure to get a thin film which was dried in vacuo overnight. The thin film was hydrated in $2 \mathrm{~mL}$ of a $0.3 \mathrm{M}\left(\mathrm{NH}_{4}\right)_{2} \mathrm{SO}_{4}$ solution and 15 glass beads were added. The mixture was rotated on a rotary evaporator for $1.5 \mathrm{~h}$ at $65{ }^{\circ} \mathrm{C}$. The suspension was decanted and refilled to $2 \mathrm{~mL}$ by $0.3 \mathrm{M}\left(\mathrm{NH}_{4}\right)_{2} \mathrm{SO}_{4}$ solution. The suspension was homogenized by sonication with a Bandelin ultrasonic homogenizer HD 3100 with maximum amplitude of $20 \%$ for $3 \mathrm{~min}, 5 \mathrm{~min}, 7 \mathrm{~min}, 5 \mathrm{~min}$ and $12 \mathrm{~min}$ (each with few seconds break). Remaining ammonium sulfate was removed by size exclusion chromatography (Sephadex G50) using $0.1 \mathrm{M}$ PBS-solution as eluent. The solid drug was doused with the purified liposomes and stirred for $1.5 \mathrm{~h}$ at $65{ }^{\circ} \mathrm{C}$. Nonencapsulated drug was removed by another size exclusion chromatography (Sephadex G50; eluent: PBS). The liposomes were stored at $4{ }^{\circ} \mathrm{C}$ until further usage. Under these storage conditions, the liposomes were stable for more than 3 months, without any change in activity (data not shown).

For cell uptake studies, fluorescent-labeled liposomes (loaded with 2) were prepared as described above and $0.43 \mathrm{mg}$ NBD-DSPE was added before the preparation of the thin film. The concentration used of these liposomes is referred to the attached fluorophore (0.12 $\mathrm{mM})$.

\section{Particle size and surface charge (zeta-potential)}

The particle sizes and the polydispersity indices (PDI) were determined by dynamic light scattering (DLS) using a Malvern ZetaSizer Nano ZS (Malvern Instruments Ltd., Malvern, UK) equipped with a $4 \mathrm{~mW} \mathrm{He}-\mathrm{Ne}, 632.8 \mathrm{~nm}$ laser beam at $25^{\circ} \mathrm{C}$ and at a scattering angle of $173^{\circ}$. Prior to the particle size measurement, the nanoparticles were diluted with $(1: 9 \mathrm{v} / \mathrm{v})$ Millipore water, liposomes were diluted $(1: 9 \mathrm{v} / \mathrm{v})$ with PBS and both measured in disposable cuvettes (UV-cuvette micro, Brand $\mathrm{GmbH}+\mathrm{Co} \mathrm{KG}$, Germany). The zeta-potential was determined using the same instrument in disposable capillary cells.

\section{TEM measurements}

Liposomes were analyzed with negative stain electron microscopy using a Zeiss TEM 902 electron microscope. One drop (approximately $10 \mu \mathrm{L}$ ) of the diluted liposome suspension $(1: 9$ $\mathrm{v} / \mathrm{v}$, with Millipore water) was placed on a carbon-coated 100-mesh copper grid. Any excess fluid was removed with a filter paper. The grid was allowed to dry overnight. A 2.5\% gadolinium acetate solution was used as staining agent and, after $1 \mathrm{~min}$, the excess was drawn off with a filter paper and the sample analyzed under the electron microscope.

\section{Determination of the encapsulated drug amount}

Aliquots of $50 \mu \mathrm{L}$ of the nanoparticle/liposome containing solutions were dried under reduced pressure by a rotary evaporator. In case of nanoparticles the thin film was dissolved in acetone : dichloromethane $(1: 1, \mathrm{v} / \mathrm{v})$ and in case of liposomes in PBS : $\mathrm{MeOH}(1: 1, \mathrm{v} / \mathrm{v})$ and sonicated for $5 \mathrm{~min}$. The amount of encapsulated drug was determined by UV-Vis spectroscopy on an Agilent 8453 UV-Visible system (Agilent Technologies,
Germany) using a calibration curve of the drug. The samples were measured in $10 \mathrm{~mm}$ path length quartz cuvettes.

\section{Stability and reproducibility of particle size}

Three batches of freshly prepared nanoparticles and liposomes were investigated to determine the reproducibility in size and drug loading. Therefore, the mean diameter and PDI of three independent batches was measured by DLS and the drug content was analyzed by UV-Vis spectroscopy as described above. Furthermore, long-term stability studies over a 100 days and heat stability at $37{ }^{\circ} \mathrm{C}$ for $24 \mathrm{~h}$ were carried out by determination of the particle sizes with DLS as described above.

\section{Drug release studies}

The dialysis bag diffusion technique was used to study the drug release. Drug-loaded particles were freshly prepared and added into a dialysis membrane (average flat width of $10 \mathrm{~mm}$ and molecular weight cut off of $12.5 \mathrm{kDa}$ (Sigma Aldrich, Austria)). The membrane was closed and immersed into a $0.1 \mathrm{M}$ phosphate-buffered saline (PBS) solution $\mathrm{pH}=7.4$ at $37 \pm 1{ }^{\circ} \mathrm{C}$ with continuous stirring at $200 \mathrm{rpm}$. To determine the amount of diffused drug through the dialysis membrane, $1 \mathrm{~mL}$ samples were withdrawn from the solution at fixed time intervals $(0 \mathrm{~min}$, $1 \mathrm{~h}, 3 \mathrm{~h}, 6 \mathrm{~h}, 24 \mathrm{~h}, 48 \mathrm{~h}$ and $72 \mathrm{~h}$ ) and replaced by fresh PBS solution. The drug concentration was measured by fluorescence spectrophotometry (Horiba Jobin Yvon, FluoroMax 4) at rt (excitation wavelength $368 \mathrm{~nm} /$ emission wavelength $455 \mathrm{~nm}$ ). As positive control stock solutions of the free drug in DMSO were diluted to the concentration of the drug in the nanoformulations by $0.1 \mathrm{M}$ PBS (final DMSO concentration $\leq 1 \%$ ). The solution was placed into the dialysis bag and the drug content in the outer compartment was determined as described for the nanoformulations. The maximum value of released free drug was set to $100 \%$.

Subsequently, release profiles of liposomal formulations were tested for their suitability to zero order, first order and Higuchi models ${ }^{29}$ by the determination of $R^{2}$ value using GraphPad Prism software.

\section{Methemoglobin formation}

Prior to kinetic measurements, fresh solutions of $\mathrm{HbO}_{2}$ were prepared by dissolving human hemoglobin ( $c a .40 \mathrm{mg}$ ) in $2 \mathrm{~mL}$ of $0.1 \mathrm{M}$ PBS and reducing the metalloprotein by incubation with an excess of sodium dithionite ( $c a .5 \mathrm{mg}$ ) for $1.5 \mathrm{~h}$ at rt. The resulting solution was purified by gel filtration (Sephadex G-25) and PBS as eluent. The concentration of $\mathrm{HbO}_{2}$ was determined from the extinction coefficient of the protein at $542 \mathrm{~nm} .{ }^{41}$ Stock solutions of $2(5 \mathrm{mM})$ and $\mathrm{Fe}\left(\mathrm{NO}_{3}\right)_{3}(50 \mathrm{mM})$ were prepared in MeOH. LP-2 and 2 were incubated with $\mathrm{Fe}\left(\mathrm{NO}_{3}\right)_{3}$ in a $2: 1$ molar ratio for $10 \mathrm{~min}$ at $\mathrm{rt}$ and diluted with $0.1 \mathrm{M}$ PBS (maximum $\mathrm{MeOH}$ content did not exceed 1\%). For kinetic studies, the incubated solutions (final concentration referred to 2: $50 \mu \mathrm{M}$ ) and $\mathrm{HbO}_{2}$ (final concentration: $5 \mu \mathrm{M}$ total heme) in PBS were measured over 20 minutes using a Perkin Elmer UV-Vis spectrometer Lambda 35 over 10 cycles (300-650 nm; scan-speed $480 \mathrm{~nm} \min ^{-1}$ ). 2 and $\mathbf{L P}-2$ (as negative control) were 
measured without the prior incubation with $\mathrm{Fe}\left(\mathrm{NO}_{3}\right)_{3}$ (final concentration $\mathrm{HbO}_{2} 5 \mu \mathrm{M}$ total heme and drug $50 \mu \mathrm{M}$ ). For quantification the concentrations of $\mathrm{HbO}_{2}$ and metHb were determined at 577 and $630 \mathrm{~nm}$ after subtraction of the controls $\left(\mathrm{HbO}_{2}\right.$ or the compound alone at $\left.630 \mathrm{~nm}\right)$ from the extinction coefficient. $^{41}$

To assess the metHb formation in vivo mice were treated intravenously with 2 or LP-2 (drug concentration each $3 \mathrm{mg}$ $\mathrm{kg}^{-1}$ ). After $60 \mathrm{~min}$, mice were anesthetized and blood collected by heart puncture in a heparine tube. Lysis of red blood cell compartment was performed as previously published. ${ }^{39}$ Quantification of $\mathrm{HbO}_{2}$ and metHb levels was performed as before.

\section{Cell culture}

The human colon cancer cell line SW480 was from ATCC (VA, USA) and grown in MEM growth media. The human ovarian cancer cell line A2780 was purchased from Sigma-Aldrich (MO, USA) and grown in RPMI-1640 growth media. The murine colon cancer cell line CT-26 (from ATCC) was grown in DMEM/F12 medium (Sigma). Culture growth media were supplemented with $10 \%$ fetal calf serum (FCS) (PAA, Pasching, Austria). Cell cultures were grown and maintained in a cell incubator $\left(37^{\circ} \mathrm{C}\right.$, $5 \% \mathrm{CO}_{2}$, and humidified atmosphere) and periodically checked for mycoplasma contamination. Authentication of cell models was performed by short tandem repeat (STR) fingerprint.

\section{Cell viability assay}

Activity of the investigated compounds was tested in 2 to $4 \times$ $10^{3}$ cells per well seeded in 96-well plates. After $24 \mathrm{~h}$ recovery, cells were treated with the investigated compounds diluted in respective culture media at indicated concentrations and incubated for $72 \mathrm{~h}$. Cell viability was measured with 3-(4,5dimethylthiazol-2-yl)-2,5-diphenyltetrazolium bromide (MTT)based vitality assay (EZ4U; Biomedica, Vienna, Austria) following the manufacturer's recommendations. IC $_{50}$ values were calculated from dose response curves using GraphPad Prism software (La Jolla, USA).

\section{Uptake of liposomal particles}

The uptake of NBD-labeled liposomes (NBD-LP-2) loaded with 2 was measured by flow cytometry and fluorescence microscopy. For flow cytometry, 2-4 $\times 10^{5}$ cells per well were seeded in 6well plates $24 \mathrm{~h}$ prior to treatment. Cells were incubated with NBD-LP-2 (end concentration $7 \mu \mathrm{M}$ NBD) at $37{ }^{\circ} \mathrm{C}$ and $4{ }^{\circ} \mathrm{C}$ for $1 \mathrm{~h}$. After incubation, cells were washed twice with ice-cold PBS and detached with trypsin. Cells were washed twice with ice-cold PBS and immediately measured using a BD LSRFortessa $^{\text {TM }}$ Flow cytometer (BD Biosciences, NJ, USA). Total fluorescence was further analyzed using Flowing Software (University of Turku, Finland).

For microscopy experiments, $3 \times 10^{5}$ cells were seeded in ibidi $15 \mu$ slides (8-well) with $180 \mu$ m polymer coverslips (Martinsried, Germany). After incubation with NBD-LP-2 (end concentration $33 \mu \mathrm{M} \mathrm{NBD}$ ) for $1,6,18$ and $24 \mathrm{~h}$, cells were washed with ice-cold PBS, fixed with $4 \%$ paraformaldehyde (PFA) for $20 \mathrm{~min}$, washed with ice-cold PBS and finally stained with $0.5 \mu \mathrm{g} \mathrm{mL}{ }^{-1}$ DAPI for 5 min. After washing with distilled/ deionized $\mathrm{H}_{2} \mathrm{O}$, cells were acquired in differential interference contrast (DIC), DAPI (blue) and NBD (green) channels using an inverted microscope (Nikon Eclipse Ti, Life-Cell Imaging from Visitron Systems, Germany).

\section{Animal experiments}

All animal experiments were approved by the local ethics commission and carried out according to the Austrian and FELASA guidelines for animal care and protection. Six- to eightweek-old female Balb/c mice (weighing $\sim 20 \mathrm{~g}$ ) were purchased from Harlan Laboratories, San Pietro al Natisone, Italy. The animals were kept in a pathogen-free environment, and every procedure was done in a laminar airflow cabinet.

Murine CT-26 cells $\left(5 \times 10^{5}\right)$ were injected subcutaneously into the right flank of female Balb/c mice. Animals were intravenously treated with the drugs $\left(4 \mathrm{mg} \mathrm{kg}^{-1}\right.$ dissolved in PBS) on days 3-7 and 10-14. Animals were controlled for distress development every day, and tumor size was assessed regularly by caliper measurement. Tumor volume was calculated using the formula: length $\times$ width $^{2} / 2$.

\section{Acknowledgements}

We thank Mag. Gerhard Zeitler for devoted animal care and Thomas Mohr for help with the release kinetic models. Daniela Gruber of the Core Facility Cell Imaging and Ultrastructure Research of the University of Vienna for introduction and help concerning the TEM measurements. This work was supported by the exploratory focus "Functionalized Materials and Nanostructures" of the University of Vienna, the Austrian Science Fond (FWF) grant P22072 (to W. Berger), the Mahlke geb. Obermann-Stiftung of the University of Vienna FA526009 (to B. Keppler) and was performed with the help of the COST action CM1105.

\section{References}

1 M. Kolberg, K. R. Strand, P. Graff and K. K. Andersson, Biochim. Biophys. Acta, Proteins Proteomics, 2004, 1699, 1-34.

2 D. J. R. Lane, T. M. Mills, N. H. Shafie, A. M. Merlot, R. Saleh Moussa, D. S. Kalinowski, Z. Kovacevic and D. R. Richardson, Biochim. Biophys. Acta, Rev. Cancer, 2014, 1845, 166-181.

3 Y. Aye, M. J. C. Long and J. Stubbe, J. Biol. Chem., 2012, 287, 35768-35778.

4 G. Y. Lui, Z. Kovacevic, V. Richardson, A. M. Merlot, D. S. Kalinowski and D. R. Richardson, Oncotarget, 2015, 6, 18748.

5 C. Santini, M. Pellei, V. Gandin, M. Porchia, F. Tisato and C. Marzano, Chem. Rev., 2013, 114, 815-862.

6 P. J. Jansson, D. S. Kalinowski, D. J. Lane, Z. Kovacevic, N. A. Seebacher, L. Fouani, S. Sahni, A. M. Merlot and D. R. Richardson, Pharmacol. Res., 2015, 100, 255-260.

7 http://www.clinicaltrials.gov.

8 F. J. Giles, P. M. Fracasso, H. M. Kantarjian, J. E. Cortes, R. A. Brown, S. Verstovsek, Y. Alvarado, D. A. Thomas, 
S. Faderl, G. Garcia-Manero, L. P. Wright, T. Samson, A. Cahill, P. Lambert, W. Plunkett, M. Sznol, J. F. DiPersio and V. Gandhi, Leuk. Res., 2003, 27, 1077-1083.

9 J. E. Karp, F. J. Giles, I. Gojo, L. Morris, J. Greer, B. Johnson, M. Thein, M. Sznol and J. Low, Leuk. Res., 2008, 32, 71-77.

10 B. Ma, B. C. Goh, E. H. Tan, K. C. Lam, R. Soo, S. S. Leong, L. Z. Wang, F. Mo, A. T. C. Chan, B. Zee and T. Mok, Invest. New Drugs, 2007, 26, 169-173.

11 J. J. Knox, S. J. Hotte, C. Kollmannsberger, E. Winquist, B. Fisher and E. A. Eisenhauer, Invest. New Drugs, 2007, 25, 471-477.

12 K. Pelivan, W. Miklos, S. van Schoonhoven, G. Koellensperger, L. Gille, W. Berger, P. Heffeter, C. R. Kowol and B. K. Keppler, J. Inorg. Biochem., 2015, DOI: $10.1016 /$ j.jinorgbio.2015.10.006.

13 C. A. Kunos, T. Radivoyevitch, S. T. Ingalls and C. L. Hoppel, Future Oncol., 2012, 8, 145-150.

14 N. Portney and M. Ozkan, Anal. Bioanal. Chem., 2006, 384, 620-630.

15 H. Maeda, H. Nakamura and J. Fang, Adv. Drug Delivery Rev., 2013, 65, 71-79.

16 B. Mishra, B. B. Patel and S. Tiwari, Nanomedicine: Nanotechnology, Biology and Medicine, 2010, 6, 9-24.

17 Y. Barenholz, J. Controlled Release, 2012, 160, 117-134.

18 J. P. May, E. Undzys, A. Roy and S.-D. Li, Bioconjugate Chem., 2016, 27, 226-237.

19 I. V. Zhigaltsev, G. Winters, M. Srinivasulu, J. Crawford, M. Wong, L. Amankwa, D. Waterhouse, D. Masin, M. Webb, N. Harasym, L. Heller, M. B. Bally, M. A. Ciufolini, P. R. Cullis and N. Maurer, J. Controlled Release, 2010, 144, 332-340.

20 T. Musumeci, C. A. Ventura, I. Giannone, B. Ruozi, L. Montenegro, R. Pignatello and G. Puglisi, Int. J. Pharm., 2006, 325, 172-179.

21 K. S. Soppimath, T. M. Aminabhavi, A. R. Kulkarni and W. E. Rudzinski, J. Controlled Release, 2001, 70, 1-20.

22 E. Leo, B. Brina, F. Forni and M. A. Vandelli, Int. J. Pharm., 2004, 278, 133-141.

23 R. Mackenzie, J. Booth, C. Alexander, M. C. Garnett and C. A. Laughton, J. Chem. Theory Comput., 2015, 11, 27052713.

24 S. Puri, P. Kallinteri, S. Higgins, G. A. Hutcheon and M. C. Garnett, J. Controlled Release, 2008, 125, 59-67.

25 Q. Miao, D. Xu, Z. Wang, L. Xu, T. Wang, Y. Wu, D. B. Lovejoy, D. S. Kalinowski, D. R. Richardson and G. Nie, Biomaterials, 2010, 31, 7364-7375.
26 D. Zucker, D. Marcus, Y. Barenholz and A. Goldblum, J. Controlled Release, 2009, 139, 73-80.

27 É. A. Enyedy, É. Zsigó, N. V. Nagy, C. R. Kowol, A. Roller, B. K. Keppler and T. Kiss, Eur. J. Inorg. Chem., 2012, 2012, 4036-4047.

28 É. A. Enyedy, N. V. Nagy, É. Zsigó, C. R. Kowol, V. B. Arion, B. K. Keppler and T. Kiss, Eur. J. Inorg. Chem., 2010, 2010, 1717-1728.

29 V. Raju and K. V. Murthy, Indian J. Pharm. Sci., 2011, 73, 527536.

30 H. Ocal, B. Arica-Yegin, I. Vural, K. Goracinova and S. Calis, Drug Dev. Ind. Pharm., 2014, 40, 560-567.

31 S. K. Adesina, A. Holly, G. Kramer-Marek, J. Capala and E. O. Akala, J. Pharm. Sci., 2014, 103, 2546-2555.

32 H. Grohganz, I. Tho and M. Brandl, Eur. J. Pharm. Biopharm., 2005, 59, 439-448.

33 H. Zhang, F. M. Zhang and S. J. Yan, Int. J. Nanomed., 2012, 7, 2901-2910.

34 A. Hioki, A. Wakasugi, K. Kawano, Y. Hattori and Y. Maitani, Biol. Pharm. Bull., 2010, 33, 1466-1470.

35 T. Sun, Y. S. Zhang, B. Pang, D. C. Hyun, M. Yang and Y. Xia, Angew. Chem., Int. Ed., 2014, 53, 12320-12364.

36 Y. Sadzuka, K. Kishi, S. Hirota and T. Sonobe, J. Liposome Res., 2003, 13, 157-172.

37 L. Feun, M. Modiano, K. Lee, J. Mao, A. Marini, N. Savaraj, P. Plezia, B. Almassian, E. Colacino, J. Fischer and S. MacDonald, Cancer Chemother. Pharmacol., 2002, 50, 223-229.

38 J. Murren, M. Modiano, C. Clairmont, P. Lambert, N. Savaraj, T. Doyle and M. Sznol, Clin. Cancer Res., 2003, 9, 4092-4100.

39 P. Quach, E. Gutierrez, M. T. Basha, D. S. Kalinowski, P. C. Sharpe, D. B. Lovejoy, P. V. Bernhardt, P. J. Jansson and D. R. Richardson, Mol. Pharmacol., 2012, 82, 105-114.

40 M. T. Basha, J. Bordini, D. R. Richardson, M. Martinez and P. V. Bernhardt, J. Inorg. Biochem., 2015, DOI: 10.1016/ j.jinorgbio.2015.12.004.

41 W. G. Zijlstra, A. Buursma and W. P. Meeuwsen-van der Roest, Clin. Chem., 1991, 37, 1633-1638.

42 M. T. Basha, C. Rodríguez, D. R. Richardson, M. Martínez and P. V. Bernhardt, J. Biol. Inorg. Chem., 2013, 19, 349-357.

43 C. R. Kowol, R. Trondl, P. Heffeter, V. B. Arion, M. A. Jakupec, A. Roller, M. Galanski, W. Berger and B. K. Keppler, J. Med. Chem., 2009, 52, 5032-5043. 